\title{
From Democratic Socialism to a Neoliberal Agenda: A Jamaican Case Study \\ Raquel Brown
}

Raquel Brown is a graduate of the University of Toronto. She completed her Hon. Bachelors of Arts with majors in Political Science and Sociology and a minor in Caribbean Studies. She is particularly interested in the development of the global south; the links between globalization, migration, immigration and Canadian public policy.

\section{Introduction}

This paper looks at Jamaica's experience with neoliberal policies. It argues that structural adjustment policies implemented through the International Monetary Fund has undermined democracy and autonomy, as well as hindered economic development of the Jamaican economy. Further, the paper will also highlight the ways in which dependence on foreign loans reduces a government's ability to fully engage its citizens in the process of economic development. A brief but necessary historical contextualization of the formation of the two major political parties and immediate independence period of Jamaica will be outlined. A more detailed exploration of the period from 1972 to 1989 will be undertaken, as this period is characterized by the emergence of two very different ideologies in Jamaican politics. More significantly, during this period the Jamaican economy had its first introduction to neoliberal policies.

The period of 1972- 1980 will be compared to the period 1981 - 1989, as these periods are characterized by opposing political and economic ideologies, the former being democratic- socialism, the latter being a neoliberal democracy. It will be argued that during the 1970s, the government of the Peoples National Party (PNP), under the leadership of Michael Manley, had greater autonomy over the affairs of the nation than the Jamaica Labour Party of the 1980 s under Prime Minister Edward Seaga. In essence the PNP in the 1970s: 1) was able to independently decide what the country's foreign policy would look like and who its allies would be. 2) Had more freedom over its economic policies; they were able to decide what goods and services came through its wharfs for local consumption. Resulting from this, the government was in a better position to ensure the longevity of local businesses. 3) The government of the 
70 s had autonomy over the implementation of social policies; these policies included social welfare, education, and health.

\section{Historical Context}

The two party system in Jamaica was born out of a divide in the nationalist movement in 1943. Alexander Bustamante the leader of the Bustamante Industrial Trade Union (BITU) left the Peoples National Party (PNP). Bustamante formed the Jamaica Labour Party (JLP) to run against the PNP in Jamaica's first election with universal suffrage in 1944. At the time the PNP was supported by the upper-middle class and the capitalist class and was committed to Fabian socialism. The JLP on the other hand had its support in the working class and a small conservative section of the capitalist class. Both parties' ideologies became very similar over the course of time. In the 1950 os they started to drift apart, with shifted support base; the JLP attracted the middle class voters, and the formation of the national workers movement by the PNP gained them the working class vote (Stephens and Stephen, 1987).

During the period from 1950 to the 1960 s economic growth in Jamaica was rapid. Foreign investment and exports led to foreign domination over the economy, this also increased levels of social inequality within society (Girvan and Bernal 1982). Jamaica imported half its food, all of its energy and capital goods as well as a significant portion of its raw material and consumer goods. This was paid for by the bauxite and tourist industry (Stephens and Stephens, 1987). The economy grew at an average rate of 8 percent in the 1950 s and 5 percent in the 1960s. However, between 1960 and 1972 unemployment jumped by $7.5 \%$ affecting nearly a quarter of the population. Growing inequality resulted in social tensions and a rise in crime rates (Stephen and Stephen, 1987).

\section{Social-Democracy and the Manley Era 1972-1980}

Resulting from the growing inequalities of the 1960s, in 1972 the Peoples National Party was elected under the leadership of Michael Manley. Manley enjoyed wide support from various stratas of society. At this time Manley was best described as a populist; he enjoyed mass support and was not organized along specific class lines (Payne, 1994). Keeping with his mandate of 'change' the Manley government initiated numerous social projects which were aimed at improving the social and economic well being of the 
Jamaican masses (Henke, 1994). The social projects and reforms included a Land Lease project, the commitment to universal secondary education, skill training for young people, adult literacy programs, food subsidies, equal pay for women, nationalization of telephone, transport, electricity companies and recognized statutory corporations which kept him in favour with the capitalist class (Payne, 1994; Girvan and Bernal 1982). The reforms Manley undertook were aimed at creating social and political conditions that would foster social justice and improve the quality of lives of Jamaicans. For Manley, social justice is the key to national development (Manley, 1974).

In 1974, the Manley administration made a significant break from the previous government's economic directions when they announced that they were adopting democratic socialism as the parties' official ideology (Henke 1994). Democratic socialism, defined in Kaufman (1885) “...was a political economic theory under which the means of production, distribution and the exchange are owned and/or controlled by the people...political power is used to ensure that exploitation is abolished, that the opportunities of society are equally available to all and that wealth...is fairly distributed". The democratic socialist programme rejects socialism as an economic policy but preserves the right of every Jamaican to own private property. This programme called for Jamaica to diversify its economy and create private and public sector linkages (Kaufman, 1985).

The dependence of the 50 s and 6os made Jamaica more vulnerable to the economic crisis of the 70s; the country's economy simply could not absorb the sudden rise in oil prices. In 1974 Jamaica's oil bill rose from \$64 JMD million to \$177 JMD million'. Subsequently other prices rose, the impact was felt most when purchasing groceries and manufactured goods. The cost of living went up as a result. Foreign capital inflows were on a decline as was income from tourism: this created a need for alternative sources of revenue. In January 1974, the government announced its plans to renegotiate tax agreements with US and Canadian owned Bauxite companies. A production levy was to be implemented that taxed all bauxite mined or processed in the country. The initial rate of the tax was set at $7.5 \%$ of the selling price of aluminum. The revenue

\footnotetext{
1 In 1974 the exchange rate was \$1 USD $=\$ 0.90 \mathrm{JMD}$

http://www.boj.org.jm/foreign_exchange/fx_rates_annual.php
} 
generated from this moved profit from a marginal \$22 million JMD to $\$ 170$ million JMD in two years (Payne, 1994).

Increased payments from bauxite were critical to the expansion of government services. The government had also developed a National Bauxite Commission to examine the issues of revenue generation. Under Manley, Jamaica also played an instrumental role in the development of an International Bauxite Association (IBA) which has major oil exporters as its partners. The IBA countries produced 85 percent of the capitalist world's bauxite (Kaufman 1985). The formation of the IBA put Jamaica out of favour with the Kissinger administration as it promoted 'wider Third World resistance to Western economic interests' (Payne, 1994).

The Manley administration also sought to enhance self reliance. They did this by expanding their international relationships; going beyond traditional trading and economic partnerships with the US and Britain. In adopting new foreign policies, the Manly government became friendly with Cuba, and created third world trade alliances. In 1973, Manley arrived with Fidel Castro and Forbes Burnham at the Algiers Conference of Heads of State of the Non-Aligned Countries. This resulted in Jamaica being included in high profile Third World politics boosting its responsibilities in the years to come. For example, Jamaica was placed on the Security Council of the UN and Manley had been influential in negotiating a settlement in Zimbabwe and in the agitation of the New International Economic Order. Under Manley, Jamaica also took steps to expand its Bauxite exports to the USSR and Eastern Europe, however the world economic markets were not favorable to the expansion of an export led economy at this time (Kaufmann 1994).

Because of the unpredictability of international markets, the rise in oil prices, as well as an unfavorable economic climate, Manley opted to place restrictions on imports (Kaufman 1994). The main motivation behind the restrictions, Manley explained, is that reduction in imports will aid in self reliance: Jamaicans will learn to make things themselves and create local industries. This will result in the creation of more jobs for the Jamaican people. More importantly, the restrictions were an immediate response to 
economic pressures; reducing luxury imports would save much need foreign exchange for the essentials ${ }^{2}$.

Manley's new friends and trade partners continued to weaken Jamaica's relationship with the United States. The friendship reached its most tumultuous stage when Manley in 1976 supported Cuban presence in Angola. In a meeting with US Secretary of State Henry Kissinger (late 1975) Manley was asked to remain neutral on the Cuban-Angolan situation, it was implied that the much needed $\$ 100$ million USD trade credit depended on it. Days after this meeting Manley announced his support for the Cuban presence in Angola, this resulted in US economic aid being embargoed for the rest of the Ford administration's term (Payne, 1994). In 1976, attacks from the US press practically destroyed the tourist industry. Disturbances in tourism occurred alongside declining remittances and the development of a black market in Jamaica. The local Jamaican local newspaper: The Daily Gleaner, made unfounded allegations daily. The international commercial bank ceased making new loans to the country. At the same time crime was rampant; this led to claims that the CIA was trying to destabilize the Jamaican government (Girvan and Bernal 1982). The evidence supporting destabilization, albeit seemingly isolated incidents, was too much to ignore. Payne (1994) suggests that after investigating several incidents that transpired in 1976 compiled with testimony by Philip Agee, former CIA operative, there might have been destabilization underway. The USA however has denied any involvement. Blum (2004) seems to support CIA presence in Jamaica at the time. Destabilization or not, the combined result of the 1976 disturbances was a loss in the exchange reserve of a detrimental \$254 million USD (Girvan and Bernal, 1982).

Despite all the social disturbances and economic shortfalls, the PNP was re-elected for a second term in December 197. This was a testament to the appeal and effectiveness of their political and social programs (Girvan and Bernal, 1982). It should be noted however, at this time Manley could not be seen as populist. Though he had won the second term, he had lost a significant portion of his upper and middle-class following and had gained an even larger working class following (Stone, 1981). His vision of change came with sacrifice: Manley alienated himself from many of the upper and

\footnotetext{
2 Interview with Micheal Manley by Journalist Gil Noble on "Like It Is" October 28, 1977 https://www.youtube.com/watch?v=_tKvvKaQhFY
} 
middle classes when his plan of reform began to infringe on the importation and use of luxury items. In 1975, Manley unapologetically told the people that 'Jamaica has five flights a day to Miami' for those who were not willing to make the necessary sacrifices to build a new Jamaica (Weis, 2005). This statement was directed toward the middle and upper class.

The entire second term of the Manley regime was plagued by economic crisis (Stephens and Stephens, 1987). PNPs victory came at the same time as the exhaustion of the central banks liquid reserves. Within the PNP camp there were serious discussions about the economic crisis, and the IMF must have been considered as an option for alleviating the immediate economic problems. The leftleaning within the party were doubtful of the efficiency of the IMFs approach to Third World economies and argued Jamaica could survive the economic crisis by careful spending and supplementary loans of other kinds. In January 1977, Manley explained the position to Jamaican people, stating the IMF imposes difficult conditions on countries who are trying to secure loans. He went on to say 'we are the masters in our own house and in our house there shall be no masters but ourselves, Above all we are not for sale.'(Thomas, 2001). The PNPs team of economist drafted an elaborate emergency production plan that would increase self-reliance in the production of food and raw materials diversify economic relations and promote state sector investment, inter alia. The plan was rejected by the cabinet because of the anticipated repercussions (Stephens and Stephens, 1987). The IMF loans appeared to be the only options for foreign exchange at the time. Further, in a national poll conducted by Carl Stone in 1977, 76 percent of the populations were in favour of US aid. This was hardly the climate to challenge the dominance of international Capitalism. (Stone, 1980)

The Carter administration appeared to want a more friendly relationship with the Caribbean. US policy at that time appeared to be persuading Jamaica back to the 'Western camp'. The US also made known that US aid would be forthcoming if Jamaica repaired its relationship with the IMF. Jamaica resumed negotiations with the IMF. Initially the government appeared to have some bargaining power. However, in December 1977, the Bank of Jamaica exceeded its prescribed ceiling by 2.6 percent. The IMF deemed this economic mismanagement and suspended the next insulation of the loan (Payne, 1994). As Bartilow (1997) puts it, this was a 'carefully constructed trap'. The IMFs set unrealistic targets to encourage 
Jamaica's noncompliance. When these targets were not met Jamaica was introduced to 'a very stringent adjustment programme' (Bartilow, 1997). A new agreement was finally concluded in 1978, which in Manley's words, 'was one of the most savage packages ever imposed on any client government of the IMF' (Payne, 1994). The fund demanded price liberalizations, interest rate adjustments, currency devaluation and cuts to social spending. Unfortunately none of this alleviated economic decline, it had however, successfully undermined the parties goals of social reform. Over the next year, the dismal outlook of the plan led the party to seek 'non-IMF' alternatives to Jamaica's economic problems. Prime Minister Manley announced a general election one year before it was due, giving Jamaicans the opportunity to decide what economic path the country would take and whether the IMF was going to be a part of that path (Girvan and Bernal, 1982).

\section{Seaga and Jamaica's Neoliberal Agenda}

In October 1980, the Jamaican working class decided they could not sacrifice any longer. The Jamaica Labour Party, under Edward Seaga, won the elections with an overwhelming majority. His campaign emphasized 'deliverance' from the tragedies of socialism and promised 'to make money jingle in your pockets' (Henke, 1999; Weis, 2005). Seaga was very vocal about embracing pro-US foreign policy and free market domestic policies. This rhetoric was aimed at US conservatives and successfully mended Jamaican-US relations as it was well received by the Reagan administration. Following the change in rhetoric in Jamaica, the US government extended extraordinary resources to the island (Biddle and Stephens, 1989).

In addition to Jamaica's renewed relationship with Western democracy, the countries internal dynamics also changed. The style and transparency of public disclosure on topics of the economy and politics was eroded in the 1980s. The rhetoric of the 70s was based on themes such as self reliance, liberation and non alignment. In the 80 s the rhetoric was centered on the functioning of markets, macro and micro economic management with a general anti-communist sentiment (Henke 1994). The ideology of the country shifted from democratic socialism to neoliberalism. There was no room in political dialogue for critical questioning of the status quo. Questions of democracy, human rights and social development in Jamaica were completely bypassed in public debate. The focus was placed on short 
term questioning and reasoning about immediate, small scale problems of economic management. The larger issue of national development was overlooked for the most part (Haneke 1999).

In keeping with the countries new neoliberal ideologies and embracing a pro-US ideology, the government adjusted its diplomatic ties. As soon as Seaga was inaugurated, the JLP government extradited the Cuban ambassador. Shortly after, the government also withdrew its plans for regional expansionism. The local and foreign press were pleased with Sega's diplomatic decision and praised him in the media. By the end of 1981 Jamaica completely severed its relations with Cuba. This break was good for a 'US Caribbean policy scheme' which was aimed at isolating Cuba. The US commended Jamaica for their 'sovereign' decision that was 'essential to their own interest' (Henke, 1994).

In aligning himself with US foreign policy, Seaga throughout his time in office removed diplomatic ties with Grenada. The government supported the exclusion of Grenada from the Caribbean Basin Initiative, stating that Cuba and other socialist countries would take care of Grenada's needs. Seaga also supported the Barbadian Prime Minister's proposal to exclude countries from CARICOM that deviated from the norms of parliamentary democracy in the Caribbean. This was clearly designed to isolate Grenada (Libby 1990). Seaga also played an instrumental role in supporting the US invasion of Grenada, the JLP government even involved Jamaican forces (in minor roles) in the operation in 1983 (Payne 1994).

Seaga's first priority in office was to secure financial funding and prevent Jamaica from going bankrupt. In his first address to the nation, he declared there was only foreign exchange for four more days. He signed a short term loan agreement with Venezuela and committed himself to restoring Jamaica's relationship with the IMF. In April 1981 the Seaga government received its first loan of $\$ 698$ million USD. It is important to note that the IMF did not impose the harsh conditions that they imposed on the Manley government. Seaga's government was not required to devalue the Jamaican currency and there was no imposition of wage and price control (Payne 1994).

In the year following the election Jamaica emerged as one of the most committed client states to the US government in the Caribbean area (Payne 1994). Weis (2005) posits that Jamaica was 
the US's special project and it was believed that the failure of the program in Jamaica would confirm the views of the rest of the Third World. That cooperation with the IMF was a pointless undertaking. As a result by 1985 Jamaica had received twenty-seven times more per-capita USAID that did sub-Saharan Africa (Weis, 2005).

Despite the high levels of IMF/ World Bank support, the economic performance in Jamaica was dismal. By 1983 the economic situation in Jamaica was so bad that the government had to implement a two-tier exchange rate. This assisted in further devaluations of the dollar. By March of the same year Jamaica had failed its first IMF performance test under the Seaga government, by September they had failed the second (Payne 1994). The average growth rate was barely $1.2 \%$ by 1985 the country had gone to a recession. In 1988 the real GDP still had not reached the growth rate it was in the second year of Democratic Socialism. The social conditions deteriorated rapidly as a response to IMF austerity programs. Class antagonism heightened during the 8os, and the gap between the rich and the poor widened. Financial constraints reduced the government's ability to regulate (re)distribution of goods and services (Henke, 1994).

The Jamaican people were losing faith and patience with the Seaga government. Seaga was elected with a sweeping majority. In May 1981, public opinion polls showed that JLP had a $28 \%$ lead over the Manley government. By the end of that year only $7 \%$ of people in the opinion polls favour Seaga over Manley; in October 1982 the PNP pulled ahead with 43 percent favoring them and 38 percent favoring the JLP. On November 23, Seaga announced an economic plan that included further devaluations of the dollar (Payne 1994). Dr. Paul Robertson, the general secretariat of the PNP, condemned in the strongest terms the deception enacted on the Jamaican people by the Prime Minister regarding the September 30 IMF test'. The statement went on to accuse the JLP government of misrepresenting the truth about the IMF performance test. The statement also accused the government of a lack of transparency and said the country should have been immediately informed about the failure of the tests. Robertson declared that 'the only honorable thing would be for the Minister of Finance [Seaga] to resign. The People's National Party 
hereby calls for his resignation.'(Daily Gleaner, November 23, 1983) 3 .

On November 26, Prime Minister Edward Seaga announced that he would hold elections on December 15th. Sega asserted that the call for his resignation was a "challenge to my sincerity, my honesty and my integrity based upon a public statement which I made, the accuracy of which was the subject of technical interpretations between Jamaica and the IMF, the resolution of which was not concluded having been superseded by another [IMF] agreement"4. The PNP boycotted the election on grounds of illegitimacy. They stated that the elections were being held using the 1980 voters list; this would disenfranchise 150,000 young people. 5 The JLP subsequently had the largest victory in the history of Jamaican elections, claiming all seats uncontested.

Payne (1994) suggests that the snap elections were strategic. Seaga was falling out of public favour and there was real prospect that his government would be the first Jamaican government, since independence, to be removed from office after serving only one term. There were two things working in his favour: an election in 1983 would mean that the voters list would not be updated to include those who had come of age after 1980, these young people predominantly favored Manley. In public opinion polls, 40 percent of the electorate were opposed to calling elections on the old voters list (Bryan 2009). Second, Seaga was riding high on Jamaica's role in the invasion of Grenada was successful at painting the Grenadian government as illiberal without frequently held elections. He was also able to show that the PNP had taken part in the allegedly subversive meetings in Nicaragua with other Socialist International Parties in the region. Seaga in essence was effectively able to deploy the classic 'red scare.' Roberson's comments were the perfect excuse to call elections before the Grenadian effect had worn off (Payne 1994).

After his victory, Seaga remained committed to the course he had set. However during later years he was more openly critical of IMF policies. The ultimate justification for continuing a one-party system would be improved economic situation and quality of life for

3 Daily gleaner "Elections over the years" Lloyd Williams October 14, 2002 http://jamaica-gleaner.com/gleaner/20021014/news/news6.html

4 Ibid.

5 Ibid 
Jamaicans. However in the years to come the JLP government was faced with further economic deterioration and a widening gap between the rich and the poor. In the midst of economic hardship there was some progress. Despite complaints from the private sector, companies like Island Life, Highgate Chocolate and Seprod showed definite signs of growth. Kingston Free-Zone had found employment for six thousand women. Exports had increased generating much needed foreign exchange. The tourism industry was also booming showing 62 percent more growth. Despite all this growth economic recovery was elusive. In a public opinion poll taken in 1986, Jamaicans believed that their situation had worsened. After 1984, the economy had turned to negative growth. In 1985 the government's debt payments neared half the countries export earnings (Bryan 2009).

In 1985 the government signed a new IMF agreement for a loan of $\$ 120$ million JMD on the conditions that there would be further budget cuts, tighter control on credit and more cuts in the public sector. This came after 65 thousand jobs were cut in the previous two years. At this point Seaga became vocally critical of the IMF and openly stated that their policies were counter productive (Bryan 2009). The Jamaican people were disgruntled and could not take any further devaluation of the dollar. In 1986 the government took a new approach to IMF and really started to attempt bargaining: in September of that year Seaga went to Washington to discuss why he was deliberately not making payments to the IMF. This meeting was blunt, the Secretary of State for Inter-American Affairs informed Seaga to create a proper privatization process and devalue the Jamaican dollar further to its real market level. Seaga continued negotiations, he conducted some privatization measure but he knew as it related to currency devaluation he had no alternative but to hold ground. The fund relented and in January 1987 the JLP signed its fourth major agreement with the IMF (Payne, 1994).

The success of this negotiation was pivotal. For Seaga, they marked the beginning of a much more positive relationship with the IMF. The IMF relented, but there was no doubt that the devaluations would take place at the end of the loan period if the inflation target was not met. Nevertheless Seaga's negotiations bought him more time. Seaga was able to announce real GDP growth for the fiscal year 1986-1987 of 3-4\%. The main factors that accounted for this growth however were falling oil prices and growth of exports to the US under 
the 807 programmes; but most significantly, the growth of the tourist industry. It can be argued that this growth was unambiguously an achievement of the JLP government, their alignment with US foreign policy restored Jamaica's favorable world image as a holiday destination. In 1988 and the previous year, Seaga's government had significantly increased public expenditure on road building. When introducing the April 1988 budget, he announced his 'social well-being programme' which was designed to rebuild the country's social services. The political message was clear: because finances were under control, the social costs of the adjustment programme could now be tackled. In late 1988, Seaga secured another loan from the IMF without much problem. However there were accusations that aid was being distributed along party lines. This damaged JLP in the public opinion polls and the PNP reasserted itself. This was right about the time of elections; Seaga had run out of time politically. In the elections of February 1989, the PNP took 45 of 50 seats with $57 \%$ popularity.

\section{Analysis and Conclusion}

The political ideology of the 1970s was democratic socialism. This was a political economic theory under which the means of production, distribution and the exchange are owned and/or controlled by the people. Manley, the leader of the PNP, had a long term vision for the country. He wanted to create an equitable society because, for him, equity was the foundation on which development is built. As Stone (1989) puts it, Manley was seen as the 'trade unionist': someone concerned with fairness, social justice and equity for the poor. He was voted in as a populist leader in 1972; however, by the time of his re-election he had lost the vote of the upper and middle-class. Towards the end of his second term, the working class had also lost faith in Manley's ability to lift them out of poverty.

Seaga's political ideology in the 1980 s was neoliberalism. The JLP's 1980 manifesto declared the parties intention to "create a market system of economics... to shift unnecessary public enterprises to the private sector... [and the] progressive liberalization of import restrictions leading eventually to the elimination of all licensing requirements" (Wilson 1996). Seaga was seen as the manager and the fixer: he creates benefits by increasing production, income and cash flow (Stone, 1989). The Economist in 1983 noted that the manifest of 1980 was a regurgitation of the structural adjustment 
programme outlined by the IMF and World Bank (Wilson 1996). It should come as no surprise that after aligning himself with a US developmental plan, one of his first political moves was to negotiate with the IMF and begin implementing his neo liberal economic policies.

The Manley government in its quest of social democracy, subscribed to a foreign policy of non alignment, this gave the country freedom to expand its foreign affairs and trading partners beyond the traditional scope of the West, namely, the United States and Britain. In doing this the Manley government became friendly with Cuba. In his speech before the Non Alignment Movement (NAM) in Havana, Manley embraced the fraternal party relations between the Cuban Communist Party, the PNP, and the NJM of Grenada (Libby, 1990). Manley also supported the Cuban presence in Angola after being asked by Kissinger to stay neutral. This compiled with the growing number of open Marxists in Manley's cabinet was becoming increasingly threatening to the US who feared Cuba having alliances in the region.

Manley's lack of compliance with US advice and his open support for Cuba in particular raised alarms in Washington. Even if the claims of destabilization are dismissed as conspiracy the US did take harsh measures, in the direction of crippling the Manley government. The aid from the US was significantly lower after the Angolan incident. The US governments also tied aid to IMF loans, strongly implying that if the government wanted assistance they had to befriend the IMF. The US took the opportunity of the Jamaican IMF loans to implement very harsh conditions. Bartilow (1997) asserts that the IMF was not pleased with the way Manley had politicized the negotiation process (example the 'we are not for sale' speech) and undermined its autonomy.

By signing with the IMF, neoliberal policies were implemented under structural adjustment programs (SAPs) and this effectively undermined the social democratic programme. The SAPs reduced the amount of money in the budget for social spending and also attempted to regulate the economy by opening up Jamaica to cheaper imports, at the same time devaluing the dollar. A great deal of suffering came along with the IMFs SAPs, most of which had to be bore by the Jamaican people. In the election that followed, the SAPs proved to be too much of a burden for the Jamaican people and Manley was voted out of office. 
The JLP was voted in with the promise of better days. In aligning himself with a US developmental plan, Seaga and the JLP government limited its autonomy in deciding the country's foreign policy, economic policy and social policy. Libby (1990) argues that 'by aligning Jamaica's foreign policy with US foreign policy, Seaga's principal motivation was to assert his own foreign policy by rejecting Manley's policies.' In essence what Libby is implying is that Seaga was not coerced into the neoliberal agenda. He opposed Manley's democratic socialism and sought to introduce his own agenda. Libby does however acknowledge that aligning his policy with the US was very important in securing aid. Regardless of why his policy was aligned to US policy the fact that it was aligned limited his capacity to create economic policies that adequately address the social situation of Jamaicans.

Witnessing the relationship between Manley and the US, it became evident that the relationship was strained because of the PNPs fraternity with the Cuban government. Seaga as a result removed the Cuban ambassador to Jamaica and severed all diplomatic ties. Though the US had not directly told him to do so, it is well recognized that such an action supported the US. Further it aided in their 20 year long scheme to isolate Cuba from the rest of the region. The same is true of the Grenada invasion: supporting the isolation of Grenada and subsequent invasion justified US ideology. Further, it helped ensure that Cuba remained completely isolated. In essence Seaga, in aligning his policies with the US, intentional or not, was the only reason he was able to secure the substantial amount of aid that he did. His government's autonomy, as it relates to foreign policy, was curtailed in the sense that he knew he could not have chosen any other foreign policy agenda and gotten the same level of assistance that he did.

As it related to economic development the general idea in the JLP camp and among public sector supporters was that there was little conception of survival outside the IMF. As Henke (1999) puts its, it was believed that "non IMF or an IMF default would make the current hardships look like Eden.' The JLP could not offer Jamaican businessmen the level of support or protection that the Manley government had offered them, because SAPs required competitive open markets. This resulted in many small businesses hesitant to take part in open capitalism. Import substitution manufactures believed that they had been bypassed by the government who had worked out a new timetable with the IMF. Further, with new IMF 
loans the value on import substitution had decreased resulting in manufactures losing political influence. Most of these complaints came from the private sector (Henke, 1999). Money talked, and to the extent that more money was coming in from the USAID and IMF loans, the private sector lost its ability to influence government.

Because of the guidelines of SAPs it was difficult for the government to spend on social welfare. As a result, health care continued to decline as did the quality of education in the country. The gap between the rich and the poor was widening. The opening of the economy put food back on shelves in supermarkets, but the dollar was so devalued that the poor no longer had the purchasing power to buy it. Seaga, towards the end of his term, was able to undertake meaningful negotiations with the IMF. Unfortunately this came at the end of his term, so it is difficult to assess the longevity of this new relationship.

In closing there are a few important things to note. Because of Seagas alignment with the US, they were far more comfortable with him than they were with Manley. This allowed him a certain degree of leniency. First, he was not subject to the 'savage' SAPs that the Manley government had to endure. When he decided not to pay loans in protest, the US was not as hard on him as they were on the PNP. Additionally, because the JLP government was very responsive and cooperative with the US, they were better able to bargain (this only happened in the last year of the Seaga administration) so it is difficult to assess.

As a general principle, democratic governments must be able to serve the needs of the people. The economy was, in fact, experiencing growth under the JLP in the latter part of their second term. However, in public opinion polls the people thought that conditions in the country had deteriorated. According to Stone (1989) this means Jamaicans vote according to public spending, not economic growth. The people are concerned with social spending and improvements in the services that directly impact their lives, such as infrastructure, health care and education. Because of SAPs constraints, the Seaga government, like the Manley government, was not able to deliver adequate social benefits in a reasonable amount to time. As a result, they were voted out. 


\section{Work Cited}

Bartilow, Horace A. 1997. The debt dilemma: IMF negotiations in Jamaica, Grenada and Guyana. London: Caribbean.

Blum, William, and William Blum. 2004. Killing hope: U.S. military and CIA interventions since World War II. Monroe, Me: Common Courage Press.

Bryan, Patrick E. 2009. Edward Seaga and the challenges of modern Jamaica. Kingston, Jamaica: University of the West Indies Press.

Girvan, Norman \& Richard Bernal 1982. 'The IMF and the Foreclosure of Development Options: The Case of Jamaica', Monthly Review, vol. 33, no. 9, pp. 34-48

Henke, Holger. 1994. Foreign Policy and Dependency: The Case of Jamaica 1972-89. Social and Economic Studies, Vol 43. No. 1 p 181183

Henke, Holger. 1999. Jamaica's Decision to Pursue a Neoliberal Development Strategy. Latin American Perspectives, issue 108, Vol. 26 No. 5 pp 7-33

Kaufman, Michael. 1985. Jamaica under Manley: dilemmas of socialism and democracy. London: Zed Books.

Libby, Ronald. 1990. The United States and Jamaica: Playing the America Card. Latin American Perspectives. Issue 64. Vol 17 No.1 pp 86-109

Manley, Michael. 1974. The politics of change; a Jamaican testament. [London]: Deutsch

Payne, Anthony. 1988. Politics in Jamaica. London: C. Hurst.

Stephen, Evelyn \& John Stephens. 1987. The Transition to Mass Parties and Idelogial Politics: The Jamaican Experience. Comparative Political Studies, Vol 19. No. 4 pp 443-483

Stone, Carl. 1881. Jamaica's 1980 elections: What did Manley do; What Seaga need do. Caribbean Review 10, 2: 4-7, 
Stone, Carl. 1980. Democracy and clientelism in Jamaica. New Brunswick, N.J.: Transaction Books.

Stone, Carl. 1989. Carl Stone on Jamaican politics, economics \& society. Kingston, Jamaica: Gleaner Co

Thomas, Gemma. 2001. Colonialism's Children. AuthorHouse, Indiana

Weis, Tony. 2005. A Precarious Balance: Neoliberalism, crisis management, and the social implosion in Jamaica. Capital \& Class Vol 29 No.1 pp 115-147

Wilson, Bruce. 1996. From Democratic Socialism to Neoloberalim: The Metamorphose of the Peoples National Party. Studies in Comparative International Development. Vol.31 No.2 pp 58-82 